\title{
Acute pain in myocardial infarction: analysis of concept
}

Dor aguda no infarto agudo do miocárdio: análise do conceito

Dolor agudo en el infarto de miocardio: análisis del concepto

\author{
Sônia Maria Josino dos Santos ${ }^{\mathrm{a}}$ \\ Thelma Leite de Araújo ${ }^{b}$ \\ Tahissa Frota Cavalcante ${ }^{c}$ \\ Nelson Miguel Galindo Neto ${ }^{d}$
}

\section{ABSTRACT}

Objective: to analyze the concept "sharp pain" in the context of acute myocardial infarction.

Methods: conceptual analysis method proposed by Walker and Avant. This makes it possible to clarify the concept of attributes. We conducted an integrative review to assist the search of studies published in 2006 and 2012, using the descriptors 'Acute Pain' and 'myocardial infarction', through consultation to Cumulative Index to Nursing and Allied Health Literature (CINAHL), Scopus and Public / Publish Medline (PubMed) data.

Results: A sample of 29 studies was selected in which the background identified was: reduction of myocardial perfusion and / or death of myocardial tissue; attributes: quality, location, time, duration and irradiation; and consequent: report of pain, dyspnea, high heart rate, nausea, vomiting, high blood pressure, high respiratory rate, sleep disturbance, diaphoresis, fatigue, paleness, weakness, anxiety and fear.

Conclusion: The findings have clarified the attributes of the concept sharp pain in myocardial infarction.

Keywords: Sharp pain. Myocardial infarction Nurse Concept formation.

\section{RESUMO}

Objetivo: analisar o conceito "dor aguda" no contexto do infarto agudo do miocárdio.

Métodos: seguiu-se o Método de análise conceitual proposto por Walker e Avant. Este possibilita clarificar os atributos do conceito. Realizou-se uma revisão integrativa para auxiliar a busca dos estudos publicados de 2006 e 2012, utilizando-se os descritores "Dor Aguda" e "Infarto do Miocárdio", por meio de consulta às bases de dados Cumulative Index to Nursing and Allied Health Literature (CINAHL), Scopus e Public/Publish Medline (PubMed).

Resultados: selecionou-se uma amostra de 29 estudos, nos quais foram identificados os antecedentes: redução da perfusão miocárdica e/ou morte do tecido miocárdico; atributos: qualidade, localização, tempo, duração e irradiação; e consequentes: relato de dor, dispneia, frequência cardíaca elevada, náusea, vômito, pressão sanguínea elevada, frequência respiratória elevada, distúrbio do sono, diaforese, fadiga, palidez, fraqueza, ansiedade e medo.

Conclusão: os achados permitiram clarificar os atributos do conceito dor aguda no infarto do miocárdio.

Palavras-chave: Dor aguda. Infarto do miocárdio. Enfermagem. Formação de conceito.

\section{RESUMEN}

Objetivo: analizar el concepto de "dolor agudo" en el contexto del infarto agudo del miocardio.

Métodos: seguimos el método de análisis conceptual propuesto por Walker y Avant. Este permite aclarar los atributos del concepto. Efectuamos una revisión integradora para ayudar en la búsqueda de los estudios publicados entre los años 2007 y 2009, utilizando los descriptores 'Dolor Agudo' e'Infarto del Miocardio', por medio de consultas a las bases de datos Cumulative Index to Nursing and Allied Health Literature (CINAHL), Scopus y Public/Publish Medline (PubMed).

Resultados: se ha seleccionado una muestra de 29 estudios, donde se han identificado los antecedentes: reducción de la perfusión miocárdica y/o muerte del tejido miocárdico; atributos: calidad, localización, tiempo y duración, e irradiación; y consiguientes: relato del dolor, disnea, frecuencia cardiaca alta, nausea, vómito, presión arterial alta, frecuencia respiratoria alta, desórdenes del sueño, diaforesis, fatiga, palidez, debilidad, ansiedad y miedo.

Conclusión: los resultados permitieron la aclaración del concepto de dolor agudo en el infarto del miocardio.

Palabras clave: Dolor agudo. Infarto del miocardio. Enfermería. Formación de concepto.
D0l: http://dx.doi.org/10.1590/1983-

1447.2015.03.51203

\footnotetext{
a Universidade Federal de Pernambuco (UFPE), Centro Acadêmico de Vitória (UFPE/CAV), Núcleo de Enfermagem. Vitória de Santo Antão, Pernambuco, Brasil.

b Universidade Federal do Ceará (UFC). Departamento de Enfermagem. Fortaleza, Ceará, Brasil.

c Universidade da Integração Internacional da Lusofonia Afro-brasileira (UNILAB). Fortaleza, Ceará, Brasil.

d Instituto Federal de Educação, Ciência e Tecnologia de Pernambuco (IFPE), Campus Pesqueira. Bacharelado em Enfermagem. Pesqueira, Pernambuco, Brasil.
} 


\section{口INTRODUCTION}

Pain is defined as an unpleasant sensory and emotional subjective experience associated with actual or potential injuries $^{(1)}$ and represent one of the major causes of human suffering. Acute pain is that which is manifested during a short period, associated to lesions with tissue or organs, influenced by sensory, socio-affective and cultural aspects ${ }^{(2-3)}$.

Among pains of higher prevalence, there is acute chest pain, which is one of the major emergency services demands. It is a symptom caused by various potentially fatal diseases and wide differential diagnosis. Related ischemic syndromes related to cardiovascular diseases ${ }^{(2-3)}$.

Atherosclerotic coronary disease is the most common cause of acute chest pain consequent to myocardial ischemia ${ }^{(4)}$. Other causes include aortic valve disease, cardiomyopathies and spasms of the coronary arteries ${ }^{(5-6)}$. In this scenario of acute chest pain, an important condition to be considered is pain related to acute myocardial infarction (AMI), triggered by necrosis of the heart muscle caused by decreased blood flow to the heart ${ }^{(3)}$. In this injury, acute chest pain is a major symptom and often does not have its cause diagnosed. This stems from inexperience and insufficient knowledge in pain affected patient management, and prioritization in favor of those who are politraumatized, present digestive hemorrhage, etc., in the emergency room.

The complexity and multidimensional nature make it impossible to develop a proper definition for each type of pain and this takes place before the onset of pain unites with a set of emotional, motivational and cultural factors ${ }^{(5)}$. These factors, paired with the flaws of the screening system, prevent adequate research and a diagnosis definition for patients with chest pain. Screening in emergency rooms is usually performed by nurses ${ }^{(7)}$. However, many nurses do not know the clinical indicators used to systematically assess pain, underestimating the frequency of pain occurrences and ignoring the devastating effect it has on the individual(8). As a result, the pain remains undertreated and underreported.

In this context, experts from different fields carry out numerous attempts to conceptualize, qualify and quantify pain ${ }^{\left({ }^{8}\right)}$. Therefore, knowledge of the essential critical attributes that shape the concept acute pain in acute myocardial infarction is indispensable to improve the evaluation and, consequently, the nursing care. Therefore, it is necessary to seek literary references to define and name its characteristics, contribute to the assessment, characterization and treatment of its effects. In this sense, concept analysis is used to clarify and determine the attributes and, from there, emphasize the importance of proper use within the scenario of interest ${ }^{(9)}$.

Thus, to certify the origin of ischemic pain and the relationship with acute coronary syndromes, it is imperative to know the aspects related to the location, irradiation, type (or quality) of pain, from the moment the symptom appears, as well as time and duration of each episode, triggers and relief conditions.

Faced with this reality, the belief is that this conceptual analysis will contribute to promoting the development of knowledge, improving and legitimizing elements that comprise the concept acute pain, translating as an essential tool for the improvement of clinical practice and operational nursing assistance of patients with acute pain at the time of myocardial infarction.

Therefore, it is important to seek literary evidence to identify the possible precedents (predictors), critical and Subsequent attributes of acute pain in patients with acute myocardial infarction. This led to the formulation of the following question: How do the authors characterize acute pain in the context of an acute myocardial infarction? Thus, the objective of this study was to analyze the concept acute pain in the context of acute myocardial infarction.

\section{METHOD}

This is an analysis of the concept acute pain, which relates to the first chapter of the thesis ${ }^{(10)}$. The steps used followed the methodological reference of Walker and Avant's concept analysis, as follows: choice of concept; conceptual analysis objective establishment; identification of possible uses of the concept; identification of the critical factors, and background and consequence identification ${ }^{(11)}$, understanding that these allow the analysis of the concept acute pain in patients with myocardial infarction, object of this study.

The performance of the steps through a literature review to aid the search for studies and enable the theoretical structuring and construction of knowledge and evidences of concept acute pain were as follows: identification of the research question and purpose of the study, literary search, data evaluation, data analysis and presentation. The integrative review gathers and summarizes research findings on a delimited subject in a systematic and organized way, contributing to knowledge enhancement of the subject investigated ${ }^{(12)}$, which justifies this method choice.

To select the articles, on-line access to Cumulative Index to Nursing and Allied Health Literature (CINAHL), SCOPUS and Public / Publish Medline (PubMed) was used, as well as descriptors from Descriptors of Health Sciences (DeCS), 
Virtual Health Library, and the Medical Subject Headings (MeSH) of the National Library of Medicine: Acute pain and Myocardial infarction. The search through studies published from 2006 to 2012 was conducted in May and June of 2013.

The inclusion criteria were: full articles available electronically, which approach the concept to be analyzed, required to be either in the Portuguese, English or Spanish language. Letters to the editor were used as an exclusion criteria.

In face of the reference adopted for the identification of the critical factors, patient history and consequences of acute pain in the context of acute myocardial infarction, the following questions were used: What are the characteristics presented by the authors to define the concept of acute pain? What events or factors contribute to the imminence of the concept of acute pain in individuals with acute myocardial infarction? What events result from acute pain in individuals with acute myocardial infarction? What factors contribute to relieve acute pain in individuals with acute myocardial infarction?

Figure 1 shows the process of finding items in the selected databases.

Literature recommends a thorough analysis of the selected studies to assess methodological quality. This step was performed according to evidence strength classification for research evaluation by Melnyk, Fineuot-Overholt ${ }^{(13)}$, presented in Chart 1.

The fact that there was respect for ethical aspects related to copyrights of the evidence available on the subject investigated is noteworthy.

\section{RESULTS AND DISCUSSION}

The characterization of the studies showed that they originated mainly from North America (54.8\%) and Europe

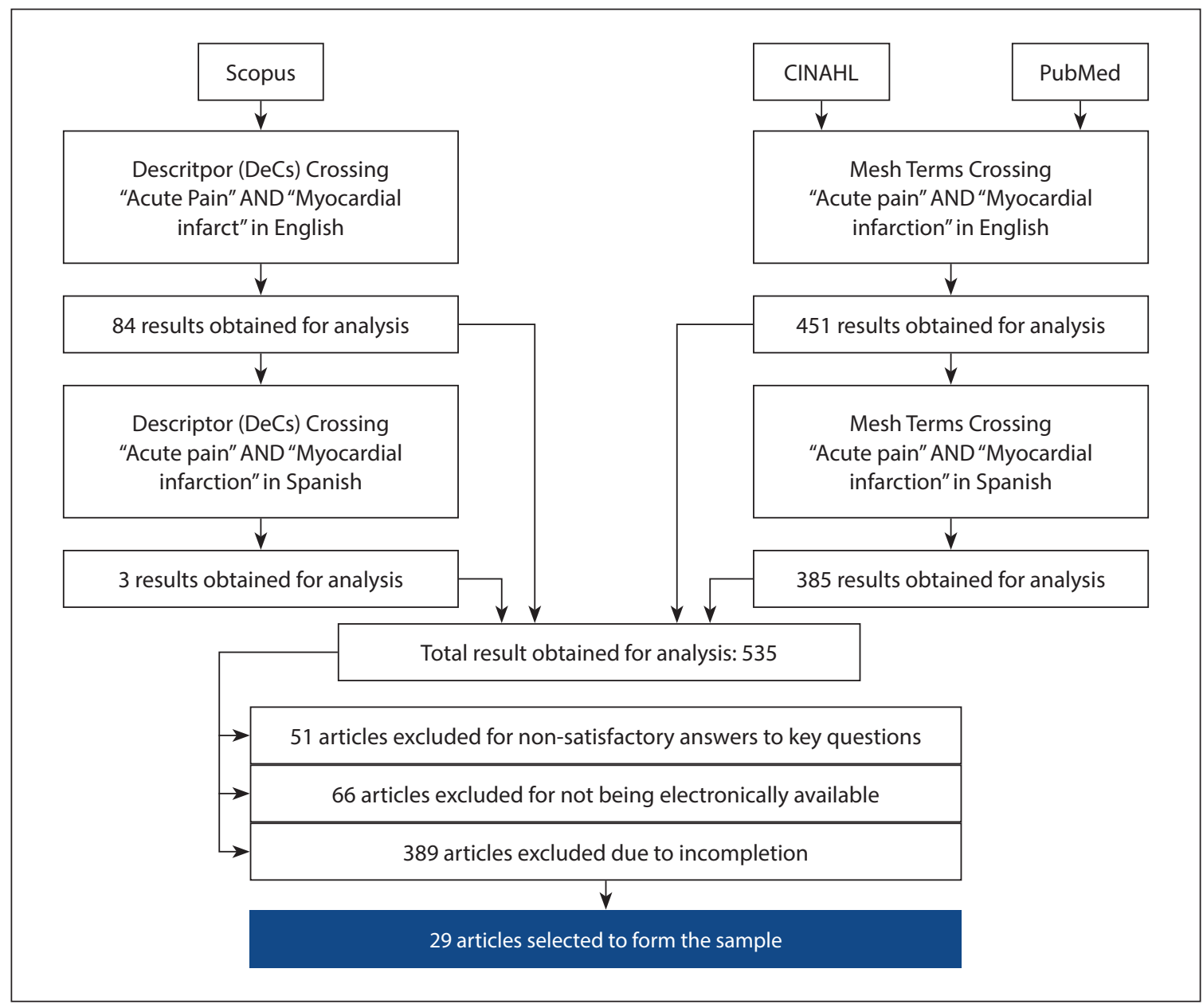

Figure 1 - Search process of studies and final selection

Source: Survey data, 2013 


\begin{tabular}{|l|c|}
\multicolumn{1}{|c|}{ Evidence Level } & $\begin{array}{c}\text { Evidence } \\
\text { Strength }\end{array}$ \\
\hline $\begin{array}{l}\text { Level 1: evidence from systematic review or meta-analysis of all relevant randomized controlled clinical } \\
\text { trials or from clinical guidelines based on systematic reviews of randomized controlled clinical trials; }\end{array}$ & \multicolumn{1}{c}{ Stronger } \\
\hline Level 2: evidence from at least one clearly designed randomized controlled clinical trial; & $\uparrow$ \\
\hline Level 3: evidence from well-designed clinical trials without randomization; & \\
\hline Level 4: evidence from cohort, and well-designed case-control studies; & $\downarrow$ \\
\hline Level 5: evidence from systematic review of descriptive and qualitative studies; & Weaker \\
\hline Level 6: evidence derived from a single descriptive or qualitative study; & \\
\hline Level 7: evidence from opinion of authorities and / or report of expert committees. & \\
\hline
\end{tabular}

Chart 1 - Evidence level rating for assessment of the studies Source: Survey data, 2013.

(45.2\%). Physicians (58.6\%) and nurses (41.4\%) performed most studies. Regarding the year of publication, $65.5 \%$ were published from 2008 to 2012, in this period there was a notable an increase of publications related to the theme, followed in years 2006 to 2008 (34.5\%). The lack of studies on acute pain in patients with myocardial infarction in South America is apparent, which is worrying, since there is a high prevalence of cases of the disease, specifically in Brazil. Studies on acute pain in myocardial infarction performed in the hospital setting predominated. Another study presented similar results ${ }^{(5)}$, which related this evidence to the seriousness and the emergency character of acute cardiovascular problems, as well as the failures of primary care in the control of risk factors.

Most studies involved adult population (86.2\%), which is supported by other research that reveals acute coronary syndromes are prevalent in people aged between 30-50 years ${ }^{(4)}$.

Descriptive or qualitative studies (24.1\%) stood out, followed by clinical trials without randomization and well-designed cohort or case-control studies with $20.7 \%$ each. Evidence from systematic review/meta-analysis and well-designed randomized clinical trial studies amounted to, respectively, $13.8 \%$ each. With regard to evidence levels of the analyzed publications, it was observed that there was a predominance of designed studies with evidence levels III and IV, followed by evidence studies of levels I and II. These findings reflect what is known about the investigated theme and points to a gap related to research with stronger clinical evidence levels that can incorporate the results in practice.

In this context, it is important to develop studies that generate better evidence to support the nursing care of patients with acute pain in myocardial infarction. It is important to emphasize that the publications with lower levels of evidence were adopted, as they helped provide relevant conceptual elements for concept acute pain analysis and its defining characteristics in patients with acute myocardial infarction.

\section{Identification of possible concept uses}

The literature review provided subsidies to identify that concept acute pain is widely used in healthcare, with greater evidence in nursing and medicine, and in the context of cardiovascular disease, specifically in coronary syndromes.

Most of the studies show that the sharp pain in myocardial infarction lasts 15 to 30 minutes ${ }^{(14-24)}$, followed by those that state the pain lasts up to 20 minutes ${ }^{(25-28)}$.

As for the onset time of the pain, studies ${ }^{(19-21,29-32)}$ report that it is sudden. Regarding the quality of pain, studies describe it as constrictive and oppressive ${ }^{(16-21,33-37)}$, as a feeling of having a crushed chest ${ }^{(21-23)}$, typically ischemic ${ }^{(38-40)}$; dilacerating and grinding ${ }^{(30-32)}$.

In most publications (14-18,22-23,25-26,33-39,41-42), acute pain in myocardial infarction is located in the retrosternal region. Pain is frequently referred to as being in the retrosternal region and is presented through distressed precordial pain, irradiated to the left superior member, with great intensity and duration that shows no improvement and no relief with rest or sublingual nitrates.

The critical attributes of sharp pain in myocardial infarction found in this study are similar to the evidence found elsewhere ${ }^{(4)}$, in which the majority of patients with acute pain in coronary syndromes had compressive, sudden retrosternal pain, with radiation to the neck, left arm, back, epigastric region and abdomen with a duration of more than 20 minutes $^{(43)}$. It was observed that all studies refer to the absence of relief factors for acute pain in myocardial 


\begin{tabular}{|c|c|c|}
\hline 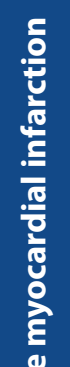 & Attributes & $\begin{array}{l}\text { Quality: constrictive, oppressive; pressure; grip and weight; crushing feeling; typically } \\
\text { ischemic; dilacerating and grinding. } \\
\text { Location: retrosternal region; substernal; thoracic; left side of the chest; center of the } \\
\text { sternum in the middle of the chest; right chest. } \\
\text { Time and duration: sudden onset; lasting; with a duration of } 15 \text { to } 30 \text { minutes; recurrent } \\
\text { and intermittent. } \\
\text { Irradiation: neck; left shoulder; jaw; interscapular region; right and left arm; back; } \\
\text { stomach; abdomen; epigastrium. }\end{array}$ \\
\hline 要 & Background & $\begin{array}{l}\text { Stent occlusion; obstruction of blood flow to the myocardium; coronary artery } \\
\text { thrombosis; reduction in coronary perfusion; emotional distress; diminished myocardial } \\
\text { perfusion; prolonged myocardial ischemia; death of myocardial tissue. }\end{array}$ \\
\hline 进 & Consequences & $\begin{array}{l}\text { Reports of pain; dyspnea; high respiratory rate; nausea; vomiting; high blood pressure; } \\
\text { elevated heart rate; sleep disturbance; diaphoresis; pallor; fatigue; weakness; anxiety; fear. }\end{array}$ \\
\hline
\end{tabular}

Chart 2 - Distribution of essential attributes, background and consequences shown in literature for the concept sharp pain in acute myocardial infarction.

Source: Survey data, 2013.

infarction. The lack of relief from chest pain with rest or nitrates suggests the cause of the pain and real possibility of an imminent myocardial infarction ${ }^{(4,43)}$.

The results revealed that the acute pain in myocardial infarction often lasts 15 to 30 minutes, irradiating to superior members and neck, and is generally followed by other associated symptoms (dyspnea, nausea, vomiting) resembling results of other studies ${ }^{(3-5,43)}$.

\section{Critical or essential attributes of the concept Acute pain}

After analyzing the concept acute pain in acute myocardial infarction, background identification, critical and consequent attributes were performed, presented hereunder in Chart 2.

From the background, attributes and consequences identified, the concept sharp pain in Acute myocardial infarction was better defined, improving its comprehension. This definition is presented below:

Retrosternal thoracic pain on the left, constrictive, oppressive, crushing, typically ischemic, sudden onset, intermittent, radiating to the neck, left shoulder, jaw, interscapular region, left arm, back, epigastrium. It is triggered by the reduction of myocardial perfusion and/or death of myocardial tissue. The pain can last from 15 to 30 minutes and set off increase in blood pressure, cardiac and respiratory frequency, besides diaphoresis, dyspnea, nausea, vomiting, anxiety, sleep disorders, fear, fatigue, pallor and weakness.
The pain causes discomfort, physiological and psychological changes and is a limiting factor for the patient. Hence the importance of identifying the characteristics that involve the concept acute pain, so that the professionals can identify it early, perform control and evaluation systematically and adopt an individualized care plan. ${ }^{(44)}$

\section{CONCLUSION}

The conceptual analysis, performed according to the Walker and Avant model, has highlighted the characteristics of acute pain in patients with Acute myocardial infarction and, from there, it was possible to observe that the concept acute pain in this clinical situation involves the presence of the following attributes: quality (constrictive, oppressive, pressure, tightness and weight, feeling of typical ischemia, rushing, dilaceration and grinding); location (retrosternal region, substernal, thoracic, on the left side of the chest, center of sternum and middle of the chest, right chest); time and duration (sudden onset, prolonged, lasting 15 to 30 minutes, recurrent and intermittent) and irradiation (neck, left shoulder, jaw, interscapular region, right and left arm, back, stomach, abdomen, epigastrium, brachial pulse and left radial). As for the pain history, the following was identified: stent occlusion; obstruction of blood flow to the myocardium, coronary artery thrombosis, reduced coronary perfusion, emotional stress, decreased myocardial perfusion, prolonged myocardial ischemia and death of the myocardial tissue, consequently, there are reports 
of pain, dyspnea, high heart rate, nausea, vomiting, high blood pressure, high respiratory rate, sleep disturbance, diaphoresis, fatigue, pallor, weakness, anxiety and fear.

The large amount of foreign publications highlighted the integrative review, justified by the frequent involvement of AMI in many countries besides Brazil should be considered as a limitation to the present study. This profile of publications may have influenced the conclusion and limited the generalization of the data to the Brazilian population, being recommended, therefore, that further research in other databases is carried out.

Despite this limitation, the study brought contributions given the evidence presented that characterize the background, critical attributes and consequences of the concept sharp pain in acute myocardial infarction. Such information becomes relevant when considering that knowledge of these characteristics will subsidize the association of pain to cardiac impairment. Thus, the professionals responsible for health promotion at various levels of care complexity, even when not experts in heart diseases or not accustomed to acting in scenarios where coronary diseases are commonly treated, may carry out a more effective decision making process in the care of patients affected by AMI.

\section{REFERENCES}

1. International Association for the Study of Pain (IASP) [Internet]. 2013 [cited in 2013 jan. 17]. Available at: http://www.iasp-pain.org.

2. Bottega FH, Fontana RT. A dor como quinto sinal vital: utilização da escala de avaliação por enfermeiros de um hospital geral. Texto Contexto Enferm [Internet]. 2010 [cited in 2014 feb. 17];19(2):283-90. Available at: http://www. scielo.br/pdf/tce/v19n2/09

3. Lopes TS, Gentile, PC, Torres AGMJ, Souza LS, Silva EP, Vilagra MM. Dor definitivamente anginosa e suas principais características. Rev Saúde [lnternet]. 2011[cited in 2014 feb. 16]; 2(2):19-28. Available at: http://www.uss.br/ pages/revistas/revistasaude/revistasaudev2n2_2011/pdf/003_Dor_Definitivamente_Anginosa.pdf

4. Paim CP, Azzolin KO, Moraes MAP. Dor torácica no infarto agudo do miocárdio entre pacientes diabéticos e não diabéticos. Rev Bras Enferm [Internet]. 2012 [cited in 2014 feb. 16];65(1):77-82. Available at: http://www.redalyc.org/ pdf/2670/267022810011.pdf

5. Lemos DM, Teixeira CSS, Polanczyk CA, Rabelo ER. Trigger Points for pain in patients with acute coronary syndrome. Rev Enferm UFSM. 2012;3(2):480-6.

6. Freitas EO, Pitthan LO, Guido LA, Linch GFC, Umann J. Factors of cardiovascular risk in a cardiology intensive care unit. J Nurs UFPE on line [Internet]. 2010 [cited in 2014 feb. 15];4(1):191-7. Available at: http://www.revista.ufpe.br/ revistaenfermagem/index.php/revista/article/download/695/1186

7. Acosta AM, Duro CLM, Lima MADS. Atividades do enfermeiro nos sistemas de triagem/classificação de risco nos serviços de urgência: revisão integrativa. Rev Gaucha Enferm [Internet]. 2012 [cited in 2014 feb 15]; 33(4):181-90. Available at: http://www.scielo.br/pdf/rgenf/v33n4/23.pdf
8. Magalhães PAP, Mota FA, Saleh CMR, Secco LMD, Fusco SRG, Gouvêa AL. Percepção dos profissionais de enfermagem frente à identificação, quantificação e tratamento da dor em pacientes de uma unidade de terapia intensiva de trauma. Rev Dor [lnternet]. 2011 [cited in 2014 feb. 15];1(3):221-5. Available at: http:// www.scielo.br/pdf/rdor/v12n3/v12n3a05.pdf

9. Lopes MSV, Saraiva KRO, Fernandes AFC, Ximenes LB. Análise do conceito de promoção da saúde. Texto Contexto Enferm [Internet]. 2010 [cited in 2014 feb. 17];19(3):461-8. Available at: www.scielo.br/pdf/tce/v19n3/a07v19n3.pdf

10. Santos SMJ. Dor aguda: revisão do diagnóstico de enfermagem em pacientes com infarto agudo do miocárdio [Tese]. Fortaleza: Universidade Federal do Ceará; 2014.

11. Walker L, Avant KC. Concept analysis. In: Walker L, Avant KC. Strategies for theory construction in nursing. California: Appleton \& Lange; 1998.

12. Whittemore R, Knafl K. Methodological issues in nursing research the integrative review: updated methodology. J Adv Nursing [Internet]. 2005 [cited in 2013 jan. 15];52(5):546-53. Available at: http://users.phhp.ufl.edu/rbauer/EBPP/whittemore_knafl_05.pdf

13. Melnyk BM, Fineout-Overholt E. Evidence-based practice in nursing \& healthcare: a guide to best practice. Philadelphia: Wolters Kluwer, Lippincott Williams \& Wilkins; 2011.

14. Hwang $S Y$, Ahn $Y$ G, Jeong MH. Atypical symptom cluster predicts a higher mortality in patients with first-time acute myocardial infarction. Korean Circ J. 2012;42(1):16-22.

15. Alomran H, Alghamdi F, Alkhattabi FB. Chest pain in a 12-year-old boy: when is it a harbinger of poor outcome? Int J Emerg Med. 2009;2(3):179-85.

16. Mccord J, Jneid H, Hollander JE, Lemos JA, Cercek B, Hsue P, et al. Management of cocaine-associated chest pain and myocardial infarction. Circulation. 2008;117:1897-907.

17. Fang BR. Acute myocardial infarction presenting with sudden death owing to cardiac rupture. J Med Ultrasound. 2012;20(4):236-9.

18. Kaur R, Lopes V, Thompson DR. Factors influencing Hong Kong Chinese patients' decision-making in seeking early treatment for acute myocardial infarction. Res Nurs Health. 2006;29(6):636-46.

19. Houck PD, StrimelWJ, Gantt DS, LinzWJ. Should we establish a new protocol for the treatment of peripartum myocardial infarction? Tex Heart Inst J. 2012;39(2):244-8.

20. Xanthos T, Pantazopoulos I, Vlachos I, Stroumpoulis K, Barouxis D, Kitsou V, et al. Factors influencing arrival of patients with acute myocardial infarction at emergency departments: implications for community nursing interventions. J Adv Nursing. 2010;66(7):1469-77.

21. Howard PK, Shapiro SE. Does gender and ethnicity impact initial assessment and management of chest pain? Adv Emerg Nurs J. 2011;33(1):4-7.

22. Mourad G, Jaarsma T, Hallert C, Stromberg A. Depressive symptoms and healthcare utilization in patients with noncardiac chest pain compared to patients with ischemic heart disease. Heart Lung. 2012;41(5):446-55.

23. Wiedemar L, Schimid JP, Muller J, Wittmann L, Schnyder U, Saner H, et al. Prevalence and predictors of posttraumatic stress disorder in patients with acute myocardial infarction. Heart Lung. 2008;37(2):113-21.

24. Khan JJB, Albarran JW, Lopez V, Chair SY. Associated with acute myocardial infarction in Chinese patients: a questionnaire survey. I Clin Nurs. 2010;19(20):2720-9.

25. Albarran JW, Clarke, BA, Crawford, J.'It was not chest pain really, I can't explain itt' an exploratory study on the nature of symptoms experienced by women during their myocardial infarction. J Clin Nurs .2007;16(7):1292-301.

26. Tziallas DCH, Papathanassoglou EDE, Kastaniote CK, Fatourou M, Karanikola MN, Giannakopoulou MD. Association between subjective descriptions of coronary 
pain and disease characteristics: a pilot study in a Hellenic rural population. Intensive Crit Care Nurs. 2007;23(6):342-54.

27. Haasenritter J, Stanze D, Widera G, Wilimzig C, Abu Hani M, Sonnichsen AC, et al. Does the patient with chest pain have a coronary heart disease? does the patient with chest pain have a coronary heart disease? diagnostic value of single symptoms and signs: a meta-analysis. Croat Med J. 2012;53(5):432-41.

28. Fukuoka Y, Dracup K, Moser DK, McKinley S, Ball C, Yamasaki K, et al. Is severity of chest pain a cue for women and men to recognize acute myocardial infarction symptoms as cardiac in origin? Prog Cardiovasc Nurs. 2007;22(3):132-37.

29. Collin M.J, Weisenthal B, Walsh KM, Mc Cusker CM, Shofer FS, Hollander JE. Young patients with chest pain: 1-year outcomes. 111Am J Emerg Med. 2011; 29(3):265-70.

30. Thang ND, Karlsson BW, Bergman BO, Santos M, Karlsson T, Bengtson A, et al. Characteristics of and outcome for patients with chest pain relation to transport by the emergency medical services in a 20-year perspective. Am J Emerg Med. 2012;30(9):1788-95.

31. Gellerstedt M, Bâng A, Andréasson E, Johansson A, Herlitz J. Does sex influence the allocation of life support level by dispatchers in acute chest pain? Am J Emerg Med. 2010;28(8):922-7.

32. Nathan S. Case report: A 55-year-old woman with chest pain upon arrival to the emergency department. Am J Health-Syst Pharm. 2010;67(Suppl 7):S25-7.

33. Canto JA, Kiefe Cl, Goldberg RJ, Rogers WJ, Peterson ED, Wenger NK, et al. Differences in symptom presentation and hospital mortality according to type of acute myocardial infarction. Am Heart J. 2012;163(4):572-9.

34. Coyle MK. Depressive symptoms after a myocardial infarction and self-care. Arch Psychiatr Nurs. 2012;26(2):127-34.

35. Løvlien M.; Schei, B, Gjengedal, E. Are there gender differences related to symptoms of acute myocardial infarction? a norwegian perspective Prog Cardiovasc Nurs. 2006;21(1):14-19.
36. McSweeney JC, O'Sullivan P, Cleves MA, Lefter LL, Cody M, Moser DK, et al. Racial differences in women's prodromal and acute myocardial infarction symptoms. Am J Crit Care. 2010;19(1):63-73.

37. Kunyoshi FH, Garcia-Touchard A, Gami AS, Romero-Corral A, Van der Val A, Pusalavidyasagar $S$, et al. Day-night variation of acute myocardial infarction in obstructive sleep apnea. J Am Coll Cardiol. 2008;52(5):343-6.

38. Matura LA. In-hospital mortality characteristics of women with acute myocardial infarction. J Clin Med Res. 2009;1(5):262-6.

39. Bergman E, Malm D, Bertero C. Does one's sense of coherence change after an acute myocardial infarction? a two-year longitudinal study in Sweden. Nurs Health Sci. 2011;13(2):156-63.

40. Dalzell JR, Jackson CE, Petrie MC, Hogg KG. Acute myocardial infarction due to coronary vasospasm in a heart transplant recipient. Am J Emerg Med. 2010;28(4):539-43.

41. Coventry LL, Finn J, Bremner AP. Sex differences in symptom presentation in acute myocardial infarction: a systematic review and meta-analysis. Heart Lung. 2011;40(6):477-91.

42. Goel PK, Srivastava SK, Ashfag F, Gupta PR, Saxena PC, Agarwal R, et al. A study of clinical presentation and delays in management of acute myocardial infarction in community. Indian Heart J. 2012;64(3):295-301.

43. Marino BCA, Nascimento GA, Rabelo W, Marino MA, Marino RL. Infarto do miocárdio sem supradesnivelamento do segmento ST: características clínicas, angiográficas e evolução intra-hospitalar dos pacientes. Rev Assoc Med Minas Gerais [Internet]. 2012 [cited in 2014 feb. 15];22(1):53-8. Available at: http:// rmmg.medicina.ufmg.br/index.php/rmmg/article/viewFile/492/477

44. Pereira JMV, Cavalcanti ACD, Santana RF, Cassiano KM, Queluci GC, Guimarães TCF. Diagnósticos de enfermagem de pacientes hospitalizados com doenças cardiovasculares. Esc Anna Nery [Internet]. 2011 [cited in 2014 feb. 16];15(4):73745. Available at: http://www.scielo.br/pdf/ean/v15n4/a12v15n4.pdf

\section{Author's address:}

Sônia Maria Josino dos Santos

Av. Presidente Afonso Pena, 1312, Bessa

58035-030 João Pessoa - PB

E-mail:smjosino@gmail.com
Received: 27.10.2014

Approved: 03.07.2015 